Воронько О. О., аспірант кафедри теорії та історї держави і права ПВНЗ «Університет Короля Данила», адвокат, керівник юридичної фбірми «АРІО»

\title{
РОЗШУК МАЙНА БОРЖНИКА В ПРОЦЕСІ ВИКОНАВЧОГО ПРОВАДЖЕННЯ У ФРАНЦІІ
}

\begin{abstract}
Анотація. У статті проаналізовано основні норми французького цивільного законодавства, які регламентують процедуру розшуку майна боржників у процесі виконавчого провадження. Акцентується увага на застосуванні мережі Інтернет та інших інформаційних ресурсів, а також дозволу виконавця правосуддя оглядати місце проживання боржника і можливість отримання інформації про нього від органів місцевого самоврядування. Аналізується порядок отримання інформації про наявність банківських рахунків боржника та можливість застосування позитивного французького досвіду в Україні.
\end{abstract}

Ключові слова: виконавче провадження, боржник, розшук майна, правосуддя, виконавці правосуддя, Франція.

Постановка проблеми. У Франції у виконавців правосуддя "huissier de justice" виникають численні труднощі під час пошуку інформації щодо місцезнаходження боржника та належного йому майна. Ці пошуки займають досить тривалий час і часто $€$ безрезультатними. Вказана ситуація зумовлена, перш за все, недосконалістю законодавчої бази, а також відсутністю уніфікованих загальнонаціональних реєстрів і права прямого доступу до них виконавцями правосуддя.

Згідно із статтями 2092, 2093 Цивільного кодексу Франції все майно боржника є спільною заставою для його кредиторів; причому вартість цього майна розподіляється між ними пропорційно, якщо серед них немає тих, хто має законні підстави для переваги» [6]. Водночас враховуючи сучасні тенденції щодо дематеріалізації майна, покупки в кредит з умовою збереження права власності за продавцем, можемо констатувати, що все це значно ускладнює процедуру як пошуку майна, так і звернення на нього стягнення.

Актуальність дослідження зумовлена потребою вивчення французького досвіду врегулювання процедури розшуку майна та можливої імплементації окремих норм цивільного права Франції в українське законодавство.

Аналіз останніх досліджень і публікацій. В українській правничій науці досвід Франції у сфері процесуальних заходів стосовно вилучення майна боржників не вивчається. Тому теоретичною основою дослідження послужили наукові дослідження французьких учених Р. Кабрілака та Дж. Коухеза, Д. Лебюа, а також нормативно-правові акти та рішення судової практики.

Мета статті полягає у вивченні механізму здійснення пошуку та використання інформації виконавцями правосуддя в загальнодоступних джерелах, а також аналізі засобів пошуку інформації, які доступні виключно для виконавців правосуддя. Також доцільно вивчити функціонування паралельного ринку надання інформаційних послуг спеціалізованими підприємствами та їхній вплив на втрату значення виконавчого провадження у Франції.
Виклад основного матеріалу дослідження. Для того щоб прийняти до виконання виконавчий документ стосовно стягнення боргу, виконавцю правосуддя необхідно мати мінімум формальної інформації щодо боржника. Перші кроки до отримання такої інформації здійснюються за допомогою стягувача, потім - боржника. Стягувач, пред’являючи виконавчий документ, висловлює своє бажання стосовно того, щоби борг перед ним був погашений або певний документ чи факт доведений до відома боржника. Стягувач зазвичай володіє певною інформацією щодо боржника й повинен надати іiі виконавцю.

Як тільки боржник ідентифікований, він повинен бути чесний і відвертий із виконавцем правосуддя, що є в його інтереcax. Він зобов'язаний надати відомості стосовно свого роботодавця, вказати своє місце роботи та інформацію щодо своєї платоспроможності або своєї заборгованості [8].

Виконавець правосуддя 3 метою наповнення виконавчої справи необхідними відомостями повинен вжити власних заходів у пошуку інформації з метою належного здійснення виконавчого провадження, що було передано йому на виконання.

Одним із найпростіших і першочергових джерел інформації, що використовують виконавці, є Інтернет. Також за допомогою телефонних довідників, які мають назву «Жовті сторінки» і «Білі сторінки» "Pages jaunes et blanches", він може зібрати загальнодоступну інформацію про боржника. «Жовті сторінки» стосуються підприємців, підприємств, асоціації, об'єднань, «Білі сторінки» - фізичних осіб. Як наслідок, маючи ім'я боржника і знаючи місто його проживання, можливо отримати повну адресу його місцеперебування, так само як і номер телефону. Зрозуміло, що ці відомості не гарантують повноту і достовірність даних, однак їх варто зібрати та перевірити в будь-якому разі. Апеляційний суд міста Гренобль від 15 травня 2006 року дійшов висновку, що сторона виконавця правосуддя не надто старанно вивчала проблему, особливо той факт, що він не здійснив пошуку інформації щодо адреси місця проживання особи, якій він мав повідомити про наявність судового рішення в телефонному довіднику («Білі сторінки»), i розпочав процедуру визнання пошуку безрезультатним [11]. Водночас всі необхідні дані стосовно зацікавленої особи були в телефонному довіднику.

Досить важливим у пошуку інформації, що стосується боржника-юридичної особи, є сайт канцелярії Комерційного суду "greffe du tribunal de commerce", однак він є платним. У витягу iз реєстру “extraits K.bis", окрім іншого, зазначено такі відомості: перейменування підприємства, ідентифікаційний номер у Реєстрі комерції і підприємств "Registre du commerce et des sociétés (RCS)”, юридична адреса, дані щодо іï керівника. 
Також можливим є отримати шляхом здійснення відповідної додаткової оплати історію внесення реєстраційних змін, стан боргових зобов'язань [4].

Стосовно отримання інформації із кадастрових та іпотечних реєстрів Франції, то іiї отримати також є можливим, однак не шляхом прямого доступу. Варто зазначити, що цей сервіс також є платним. Для того щоб здійснювати необхідний пошук, потрібно володіти інформацією щодо імені, прізвища, дати та місця народження розшукуваної особи, а також ввести індекс міста, в якому згідно з припущенням особа може володіти майном. Цей пошук здійснюється не в Інтернеті, а в кадастровому реєстрі, утримувачем якого є певна територіальна громада. Для того щоб отримати необхідну інформацію, потрібно надіслати поштовим зв'язком заявку встановленої форми, яка має назву «Запит щодо швидких невідкладних відомостей» "demande de renseignement sommaires urgents". У цьому разі пошук інформації може здійснюватися так: за адресою місцезнаходження майна (необхідно знати точну адресу об'єкта ) або за власником (необхідно вказати прізвище, ім'я, дату народження особи або назву юридичної особи).

Як результат надсилання запиту виконавець правосуддя може отримати відомості такого характеру:

- відомості, що стосуються певного об'єкта нерухомого майна (наприклад, багатоповерхового будинку);

- відомості щодо всього переліку майна, яке належить певній особі;

- відомості щодо конкретного майна, яке належить вказаній особі.

Необхідно акцентувати, що реєстри нерухомого майна у Франції не об'єднані на загальнодержавному рівні, тому виконавці часто обмежуються надсиланням запитів до тих муніципалітетів, на території яких проживає боржник, або до тих, стосовно яких є припущення, що там може бути майно боржника.

Важливим способом збору інформації виконавцем правосуддя $€$ виїзд на місце за наявними адресами місця проживання чи місця роботи боржника. Під час виїзду виконавець правосуддя може здійснювати такі дії: огляд дверних дзвінків (останні містять прізвище, ім'я особи, яка проживає за адресою), поштових ящиків, які є іменними, здійснювати опитування сусідів чи поштаря.

Ще одним джерелом інформації є мерія, яка володіє списком виборців, що є доступний для огляду всіма охочими. У цьому списку міститься, окрім іншого, ім'я, прізвище, дата та місце народження, а також адреса, які були надані виборцем під час реєстрації.

Варто звернути увагу на те, що Законом Франції від 9 липня 1991 року [17], Декретом від 31 липня 1992 року [13], Ордонансом [5, р. 395] від 21 квітня 2006 року [19], Декретом від 27 липня 2007 року [13] було проведено реформу виконавчого провадження.

Вагомим досягненням вказаної реформи, згідно 3 твердженнями французьких правників [16], було надання можливості здійснювати пошук інформації за допомогою прокурора республіки. У разі, якщо стягувач не міг надати необхідну для пошуку інформацію й виконавець правосуддя самостійно також не зміг відшукати відомості, останній змушений був звертатись із клопотанням до прокурора республіки.

Статтями 39-41 Закону Франції від 9 липня 1991 року [17] було визначено завдання прокурора республіки та його обов'я- зок допомогти в пошуку боржника. Виконавець правосуддя, перед тим як звертатись до прокурора, повинен був вжити всіх можливих заходів для пошуку боржника за останнього відомою йому адресою та скласти перелік здійснених ним безрезультатних пошуків, який надати прокурору. Тобто для того щоб надіслати запит прокурору, виконавець правосуддя повинен був до нього долучити копію виконавчого документа та перелік здійснених ним дій для пошуку боржника.

3 моменту надходження клопотання про пошук боржника прокурор республіки мав у розпорядженні три місяці для його розгляду, в іншому разі клопотання вважалось безрезультатним. Отримавши клопотання, він першочергово перевіряв зміст виконавчого документа, а також досліджував питання його чинності. У разі, якщо представлений документ не підлягав виконанню, то останній, звичайно ж, ним не виконувався. Прокурор перевіряв, чи клопотання, яке йому передано, потребує продовження процедури з пошуку боржника.

Згідно з абзацом 3 статті 54 Декрету від 31 липня 1992 року клопотання могло бути відхилено, якщо, «беручи до уваги надані документи, прокурор може також не надати продовження клопотанню і зобов’язати виконавця правосуддя здійснити додаткові пошуки або надати інші докази, якщо це йому видається необхідним» [14].

Теоретично з часу прийняття клопотання прокурор республіки повинен був вжити всіх необхідних заходів із метою пошуку боржника, а саме опитати всі структури, які є утримувачами інформації, на всій території Франції. Водночас на практиці у зв'язку із значною завантаженістю органи прокуратури не виконували вказаної роботи в повному обсязі. Досить часто розгляд клопотання значно перевищував встановлений законодавством тримісячний термін.

Прокурор республіки з метою пошуку боржника надсилав шляхом поштового зв'язку запити різним структурам, які були зобов'язані надати запитувану інформацію у визначені терміни. Варто зазначити, що отримувачі запиту прокурора під час підготовки відповіді повинні були надати всю наявну в них інформацію, у разі відсутності будь-яких відомостей щодо боржника - утримувачі інформації повинні були про це повідомити безпосередньо виконавця правосуддя.

Кодифікація вказаних вище законодавчих актів у 2012 році поклала кінець реформуванню виконавчого провадження шляхом об'єднання більшості основних диспозицій у Кодексі процедур цивільного виконання Франції [10, р. 344]. Згідно з Ордонансом від 19 грудня 2011 року № 2011-1895 [20] законодавство, яким було врегульовано процедуру виконавчого провадження до прийняття вказаного Кодексу, втратило чинність.

А також важливо зазначити, що 22 грудня 2010 року статтею 5 Закону Битея "la Loi Béteille" (положення якого ввійшли в Кодекс) було надано право виконавцям правосуддя прямо звертатись до адміністрацій і підприємств, що контролюються державою, регіонами, департаментами, які зобов'язані надати наявні в них відомості, що дають змогу виконавцю правосуддя визначити цивільний стан боржника, адресу місця проживання, адресу місцеперебування його роботодавця, склад належного йому нерухомого майна [18].

Тобто виконавці правосуддя нарешті стали більш-менш самостійними та мобільнішими в пошуку інформації.

Це твердження підтверджується також тим, що останнім часом дедалі більшого поширення набуває надсилання запи- 
тів виконавцями правосуддя засобами електронного зв'язку. Термін, протягом якого адміністрації та підприємства надають інформацію виконавцю правосуддя, залежить від термінів обновлення інформації в їхніх реєстрах.

Найчастіше запити надсилаються на пошту, енерго- і газопостачальним підприємствам «EDF et GDF», фонду страхування здоров'я "Caisse primaire d'Assurance Maladie (CPAM)", фонду соціального захисту "Caisse d'Allocations Familiales (CAF)", біржу праці "Pôle emploi" та в центри оподаткування, які володіють номерами банківських рахунків і даними щодо місцеперебування роботодавців.

Префектура є утримувачем інформації, що стосується наземних моторних транспортних засобів. Відповідно до роз'яснення суду в спорах про підсудність справ моторний транспортний засіб визначений як «об'єкт, що здатний рухатися за допомогою влаштованого в ньому пристрою». Префектура володіє доступом до Загальнонаціонального реєстру номерних знаків "Fichier national des immatriculations (FNI)", що містить дані стосовно всіх зареєстрованих транспортних засобів, які перебувають в обігу і для яких ця реєстрація є обов'язковою. У Загальнонаціональному реєстрі міститься така інформація щодо власника сертифіката про реєстрацію (ім'я, прізвище, дата народження, місце проживання, номер соціального страхування "code INSEE", а також ідентифікаційні дані транспортного засобу [3]. Наприклад, для виконавця правосуддя важливо знати дату введення в обіг автомобіля, щоб оцінити можливість звернення стягнення на нього. Якщо вік автомобіля перевищує 10 років, то його вилучення не є доцільним, оскільки його вартість не буде достатньою для відшкодування витрат на здійснення виконавчих дій.

Варто звернути увагу, що цей реєстр був замінений із червня 2009 року на Систему номерних знаків транспортних засобів SIV [12]. Згідно з цією системою транспортні засоби наділяються номерним знаком, який є незмінним, незважаючи на зміну власника транспортного засобу. Як старий, так і новий реєстри є доступними для пошуку необхідної інформації про боржника.

Відповідно до статті L339-4 Кодексу з дорожнього руху "Code de la route" виконавці правосуддя мають доступ до «інформації щодо цивільного стану власника технічного паспорта, номерного знака і характеристики транспортного засобу, а також відомості щодо застави, доступ до всієї іншої інформації є обмеженим» [7]. Для того щоб отримати інформацію щодо транспортних засобів боржника, виконавець правосуддя надсилає запит у префектуру або в супрефектуру із копією виконавчого документа.

Незважаючи на значущість інформації, яку виконавець правосуддя може отримати за допомогою вищевказаних джерел, треба зазначити, що найбільш вагомими є дані, які містяться в Реєстрі банківських рахунків "Fichier des comptes bancaires - FICOBA".

Варто згадати, що під час реформи 1991-1992 років завдання, яке ставилось законодавцем, було полегшення погашення боргу перед стягувачем. Отож законодавчо було надано перевагу накладенню арешту і зверненню стягнення саме з банківського рахунку, що $є$, порівняно із іншими видами стягнення, менш дороговартісним і менш травматичним для боржника. Варто також врахувати, що стягнення коштів із рахунку боржника не займає так багато часу, як інші види стягнення. Як наслідок, на якому ми 6 хотіли закцентувати увагу, - відсоток погашених цивільних і комерційних боргів у Франції після запровадження діяльності FICOBA значно зріс.

Водночас право прямого доступу до Реєстру банківських рахунків було надано виконавцям правосуддя лише 1 червня 2010 року. 3 цієї дати виконавці правосуддя використовують цей Реєстр прямо через їхнє програмне забезпечення або через надсилання бланку запиту "imrimé de requisition" через захищений портал (www.portail-huissier.com), що надається Асоціацією електронних прав і комунікацій ADEC. Вказаний бланк запиту є повністю дематеріалізований й адресується адміністративному центру FICOBA. Відповідь на вказаний запит виконавець правосуддя отримує в тій самій формі протягом 24 годин, яка міститься в захищеному місці, відведеному для особи, що надсилала запит. Відповідь на запит залишиться в реєстрі доти, поки вона не буде прочитаною. 3 часу ознайомлення з інформацією остання залишиться доступною ще протягом 3 днів. Після цього цей файл буде знищений безповоротно відповідно до вимог Національної комісії з питань інформації та свобод (CNIL) [1].

Вважаємо за доцільне також коротко проаналізувати, які відомості містяться в Реєстрі банківських рахунків.

Перш за все, треба зазначити, що цей Реєстр був створений у 1971 році (інформатизований у 1982 році). Законодавчою основою цього Реєстру стала стаття 1649 А Загального податкового кодексу Франції “Code général des impôts” [9], якою покладено обов'язок на всі підприємства, установи та організації, що підлягають контролю адміністративної влади, і всіх осіб, які отримують дохід від цінних паперів, акцій або готівкою, повідомити податковим органам про відкриття чи закриття банківського рахунку.

У цьому реєстрі міститься інформація щодо відкриття, зміни та закриття всіх видів банківських рахунків у Метрополії (Європейська частина Франціï) Métropole i Заморських департаментах і територіях "départements d'outre-mer / territoires d'outre-mer DOM-TOM", а саме: спільних, поштових, ощадних та інших, що належать фізичним чи юридичним особам. Для Мойотт і територій Сен-Пьєр і Мікелон декларування здійснюється в FICOM - Реєстрі, який ведеться і утримується Емісійним інститутом заморських територій Франції "Institut d'émision d'outre mer". А також у Реєстрі наявна інформація, яка походить від податкового декларування, іiі наповнення покладається на органи, що обслуговують рахунки, і контролюється загальною Генеральною дирекцією публічних фінансів "Direction générale des finances publiques DGFP".

Важливим моментом є те, що в Реєстрі наявна інформація щодо рахунків, однак вона не містить відомостей щодо руху коштів на них.

Забезпечення утримання Реєстру та його оновлення (ідентифікаційні дані, зміна назви, юридичної адреси) здійснюється Генеральною дирекцією публічних фінансів "Direction générale des finances publiques DGFP» за допомогою програмного забезпечення SIRENE".

Надання інформації для іiї внесення в Реєстр здійснюється банками впродовж місяця після відкриття чи закриття рахунку. Відповідно до статті 3 постанови від 14 червня 1982 року [2] у вказаному Реєстрі інформація зберігається протягом 10 років після реєстрації інформації про закриття рахунку, належного як фізичній, так і юридичній особі. 
У Реєстрі банківських рахунків містяться такі дані щодо фізичних осіб: назва і адреса установи, де відкритий рахунок, номер, вид, тип і характеристики рахунку, дата і вид задекларованої операції (відкриття, закриття, зміна), а також ім'я, прізвище, дата і місце народження, адреса власника рахунку та номер "SIRET Système Informatique pour le Répertoire des Entreprises sur le Territoire" приватного підприємця. Стосовно юридичних осіб наявні дані стосовно назви, організаційно-правової форми, номер SIRET, адреси місцезнаходження [15].

Як показує досвід Франції, запровадження та використання системи обліку банківських рахунків значно підвищило рівень виконання судових рішень завдяки стягненню коштів із рахунків боржників.

Цей досвід може бути корисний для України, оскільки сьогодні відповідно до нашого законодавства про виконавче провадження інформацію про рахунки боржника виконавець отримує шляхом направлення запиту до Державної фіскальної служби України. Водночас Державною фіскальною службою України надається інформація лише про наявні рахунки в боржників - юридичних осіб та / або фізичних осіб-підприємців. Отримати інформацію про наявні рахунки в боржників фізичних осіб можливо лише шляхом направлення запитів до всіх банківських установ країни, оскільки централізований облік таких рахунків в Україні сьогодні відсутній.

Висновки. Отже, пошук і збір інформації про боржника та його майно є досить складною процедурою, яка займає значну частину часу в роботі виконавця правосуддя. Незважаючи на надання права виконавцям правосуддя безпосередньо здійснювати пошук інформації без звернення до прокурора республіки, досить частими $€$ випадки, коли боржник впродовж періоду, протягом якого виконавець правосуддя здійснює пошук інформації, організовує свою неплатоспроможність, якщо це фізична особа, і розпочинає процедуру ліквідації, якщо йдеться про юридичну особу. За таких обставин у Франції сформувалась і діє велика кількість спеціалізованих підприємств, які займаються пошуком інформації. Діяльність таких компаній не регламентована законодавством.

\section{Jimepamypa:}

1. ADEC. URL: http://www.adec-sas.com/project/ficoba.

2. Arrêté du 14 juin 1982 relatif à l'extension d'un système automatisé de gestion du fichier des comptes bancaires URL: https:// www.legifrance.gouv.fr/affichTexte.do;jsessionid=8B5268608E372E 98C1991AD5B6ACCA77.tplgfr24s_2?cidTexte=JORFTEXT00000 0864438\&idArticle $=\&$ dateTexte $=20180730$.

3. Arrêté du 20 janvier 1994 portant création du fichier national des immatriculations. URL: https://www.legifrance.gouv.fr/affichTexte. do?cidTexte=JORFTEXT000000363087\&categorieLien=id.

4. Arrêté du 9 février 2009 relatif aux modalités d'immatriculation des véhicules. URL: https://www.legifrance.gouv.fr/affichTexte.do;jsessi onid=9C4E7F826C2F84E307AEF577637FBFC3.tplgfr33s_2?cidTex te $=$ JORFTEXT000020237165\&dateTexte $=20100210$.
5. Cabrillac R. Dictionnaire du vocabulaire juridique 2017, 8 ème edition. Lexisnexis, 2017. $568 \mathrm{p}$.

6. Code civile. URL: https://www.legifrance.gouv.fr/telecharger_pdf.do? cidTexte=LEGITEXT000006070721

7. Code de la route. URL: https://www.legifrance.gouv.fr/affichCode.do; jsessionid $=7640 \mathrm{~F} 30 \mathrm{C} 1 \mathrm{CDAFD} 14 \mathrm{FA} 439 \mathrm{AC} 401675206 . t p l g f r 26 \mathrm{~s} 33$ ? idTexte $=$ LEGITEXT000006074228\&dateTexte $=20180712$.

8. Code des procédures civiles d'exécution. URL: https://www.legifrance. gouv.fr/affichCode.do?cidTexte=LEGITEXT000025024948.

9. Code général des impôts. URL: https://www.legifrance.gouv. fr/affichCode.do;jsessionid=7640F30C 1CDAFD14FA439 AC401675206.tplgfr26s_3?idSectionTA=LEGISCTA000027781495 $\&$ cidTexte $=$ LEGITEXT000006069577 \&dateTexte $=20180712$.

10. Couchez G., Lebeau D. Voies d'exécution. 12-ème édition, "Dalloz", 2017, $344 \mathrm{p}$.

11. Cour de Cassation, Assemblée plénière, du 31 mai 1991, 90-20.105, Publié au bulletin. URL: https://www.legifrance.gouv.fr/affichJuriJudi. do?idTexte=JURITEXT000007055344.

12. Décret n 2009-136 du 9 février 2009 portant diverses dispositions relatives aux plaques et inscriptions, à la réception et à l'homologation et à l'immatriculation des véhicules. URL: https://www.legifrance.gouv.fr/affichTexte.do?cidTexte=JORFTEX T000020236782\&fastPos $=1 \&$ fastReqId $=1931758976 \&$ categorieLi en $=$ id\&oldAction $=$ rechTexte.

13. Décret $n^{\circ} 2006-936$ du 27 juillet 2006 relatif aux procédures de saisie immobilière et de distribution du prix d'un immeuble. URL: https://www.legifrance.gouv.fr/affichTexte.do?cidTexte=JORFTEXT0 $00000607545 \&$ categorieLien $=$ cid.

14. Décret $n^{\circ} 92-755$ du 31 juillet 1992 instituant de nouvelles règles relatives aux procédures civiles d'exécution pour l'application de la loi n 91-650 du 9 juillet 1991 portant réforme des procédures civiles d'exécution. URL: https://www.legifrance.gouv.fr/affichTexte.do?cid Texte=JORFTEXT000000541408.

15. FICOBA: Fichier national des comptes bancaires et assimilés. URL: https://www.cnil.fr/fr/ficoba-fichier-national-des-comptes-bancaireset-assimiles.

16. Les limites des procédures d'exécution eu égard à la protection des données personnelle. Cécile BARRA. Mémoire. Faculté de Droit et Science politique Aix Marseille III - Master II 2008. URL: https://www.memoireonline.com/06/08/1148/limites-voies-executionprotection-donnees-personnelles.html.

17. Loi n 91-650 du 9 juillet 1991 portant réforme des procédures civiles d'exécution. URL: https://www.legifrance.gouv.fr/affichTexte.do?cid Texte $=$ JORFTEXT000000172847.

18. Loi $n^{\circ} 2010-1609$ du 22 décembre 2010 relative à l'exécution des décisions de justice, aux conditions d'exercice de certaines professions réglementées et aux experts judiciaires. URL: https:// www.legifrance.gouv.fr/affichTexte.do?cidTexte=JORFTEXT00002 3273986\&categorieLien $=i d$.

19. Ordonnance n 2006-461 du 21 avril 2006 réformant la saisie immobilière. URL: https://www.legifrance.gouv.fr/affichTexte.do?cid Texte=JORFTEXT000000639476.

20. Ordonnance n 2011-1895 du 19 décembre 2011 relative à la partie législative du code des procédures civiles d'exécution. URL: https:// www.legifrance.gouv.fr/affichTexte.do?cidTexte=JORFTEXT00002 5009816\&dateTexte $=$ 
Воронько А. А. Розыск имущества должника в процессе исполнительного производства во Франции

Аннотация. В статье проанализированы основные нормы французского гражданского законодательства, регламентирующие процедуру розыска имущества должников в процессе исполнительного производства. Акцентируется внимание на применении сети Интернет и других информационных ресурсов, а также разрешения исполнителя правосудия осматривать место жительства должника и возможность получения информации о нем от органов местного самоуправления. Анализируется порядок получения информации о наличии банковских счетов должника и возможность применения положительного французского опыта в Украине.

Ключевые слова: исполнительное производство, должник, розыск имущества, правосудие, исполнители правосудия, Франция.
Voronko O. Search for property of a debtor in a process of enforcement proceedings in France

Summary. The article analyzes the basic norms of the French civil law regulating the procedure for the search for property of debtors in the process of enforcement proceedings. Attention is focused on the use of the Internet and other information resources, as well as the permission of the justice executor to inspect the place of residence of the debtor and the possibility of obtaining information about it from the local government. The procedure for obtaining information on the presence of the debtor's bank accounts and the possibility of applying positive French experience in Ukraine are analyzed.

Key words: enforcement proceedings, debtor, property search, justice, executors of justice, France. 